its origin, for they admittedly come from Babylonia. The tradition insistently refers the origin of astrology to the Chaldæans.

Berossos the Babylonian wrote a history of his country in the third century B.C. As the tradition appears in Vitruvius, for example, the Chaldreans cast nativities, Berossos presses their astrology on his school at Cos, Antipater and Archinapolos alter the horoscope from birth to conception, and astrology grips Greco-Roman thought. The encyclopædic history of Diodoros, about 30 B.c., describes the theory and method of the Chaldreans : the events of the heavens intimate the thoughts of the gods, so the stars were observed for many ages. So astrological theory promoted astronomy. The Babylonians are said to have checked horoscopes on the recorded lives of Babylonian boys. Even if they did this for less than the 470 years of one more moderate estimate, their inductive effort, if not their deductive doctrine, must be reckoned as scientific righteousness.

Did all the Romans who fell at Cannæ have the same horoscope? Cicero's question sounds pertinent. When the birth of Firminus was nigh, a slave-woman of his father's house was also near her delivery. Messengers were posted in either house to run to the other with news of each birth. The two messengers met so exactly in the middle of the way that the two births must have happened at precisely the same instant. Yet, St. Augustine further records, Firminus was born to increasing riches and honours, but the slave-born child was born to continued slavery. Cicero and St. Augustine argue inversely against the horoscope: Cicero from one fate and different horoscopes; St. Augustine from one horoseope and different fates. Either argument might be valid if, and only if, the disposition of the heavenly bodies at birth is the singly decisive decider of destiny. Ptolemy denies that it is singly decisive.

An anticipatory reply to St. Augustine can be shortly constructed from Ptolemy's "Tetrabiblos". Famines, pestilences, wars and the like, which affect large areas, whole peoples and cities, are more surely predicted than single human actions. The effect of the stars on the human individual is conditioned by his nationality, his country and his domicile. It is also conditioned by his period, for time varies the celestial actions. Firminus and the slave were born at the same time, in the same city and among the same people, but under different social conditions. They were also differently educated. Ptolemy disclaims an astrological narrowness if previous astrologers had ignored place, weather and heredity, as Cicero, in the "De Divinatione", says they did.

Ptolemy insists on the complexities of the celestial dispositions, on the manifold causes acting on the individual, and on the present imperfections of astrology. Predictions often fail because the science is immature, but frequent shipwrecks do not destroy the art of navigation. Ptolemy's frank admission of predictive failures contrasts with the bold statement by Diodoros that when the Chaldreans prophesied about kings they were always right.

Ptolemy repudiates impostors. He claims that the science has present value in spite of imperfections or failures, and that time will increase the value. Astrology is not useless because the stars decree inevitably : if they do cause a disease, a drug may cure it. Ptolemy manifests a recognizably scientific temper in handling a now discredited hypothesis.

Scientific inquiry is not incompatible with cosmic purposes, for Galen inquired how purposive Nature purposes. It is not incompatible with Providential ordering, for Galen inquired into the natural law through which God works, though the existence of God did not seem to him to be proved. If the stars do operate divine purposes, astrology can still have its operative scheme, as Galen had his attractive forces. A force radiated from the stars is central in early astrological doctrine-Cicero notes how the Chaldæans lodge it in the zodiac, Ptolemy speaks of the force diffused from the heavens on terrestrial things, and according to Galen "we receive the force of all the stars above". This force is variously affected by the sun, moon and planets according to their positions, conjunctions and relations to the signs of the zodiac. Other powers may co-operate, such as hot or cold, and an eye is often kept on the astro. logical agency of the air.

The moon is constantly prominent in the astrological versions. It has no more power than the other planets, Galen explains, but it is nearer. The Chaldæans, Cicero tells us, were careful to note the condition of the moon and its conjunctions with the stars at the moment of birth. The moon is usually peculiarly important in astrological theory, Thorndike notes, and more distant planets often act on the earth through it. It is quite reasonably, even if unjustifiably, suspected of inflicting genethlialogy, the science of nativities, upon many minds through many centuries.

The Chaldran type of astrology is one hypothesis which marks the route of science. It seems to be an intelligible consequence of one phase in human thinking, and perhaps more so because man very earnestly wants to know what will happen.

\section{PRE-NEANDERTHAL MAN IN THE CRIMEA}

\section{BY SIR ARTHUR KEITH, F.R.S.}

$I^{\mathrm{N}}$ 1925 there appeared an annotation in L'Anthropologie $e^{1}$ directing attention to the discoveries of ancient man and of his cultures then being made in the Crimea by G. A. Bonč-Osmolovskij, conservator of the Russian Museum in Leningrad. The chief site of these discoveries was the grotto or rock-shelter of Kiik-Koba, situated in the foothills of the Yaila Mountains, which run from Sebastopol towards the Kerch Straits. In the deepest and oldest stratum of the grotto were found fossil remains of part of a human skeleton; these were reported to be Neanderthal in character; they were examined by the late Dr. Marcelin Boule, who confirmed this diagnosis. The Crimea was then the most easterly point from which Neanderthal man had been reported. Students of early man were deeply interested in the discoveries reported by their Russian colleague and have eagerly awaited his full report-so far in vain. Recently my interest in Kiik-Koba' was heightened by an article published in Man by Prof. Gordon Childe ${ }^{2}$, in which the strata of the grotto are identified as similar in age and in sequence to those which yielded the fossil men of Mount Carmel-the subject of a report pub. lished by Dr. Theodore McCown and myself in $1939^{3}$. In February of the present year (1944) a pleasant surprise awaited me ; on opening a parcel bearing the Moscow postmark, I found within a volume entitled 
-in the French translation kindly supplied by the author- "L'Homme fossile de la Grotte de KiikKoba (Crimée)". I found it to be Part 2 of the "Paleolit Kryma"*, published in Moscow in 1941. Part 1, which gives an account of the strata of the grotto and of their contents, was published in 1940 . Inside the cover of the book which came to me so unexpectedly, the author has written an inscription in English ; it is signed G. A. Bonč-Osmolovskij and dated December 10, 1942. Considering the obstacles which lay between the author and myself, the wonder is, not that the book took more than a year to reach me, but that it ever arrived.

As I came to know the contents of this book, which was made possible for me by the author's full résumé in French and by his supplying the numerous illustrations with legends in that language, I saw why we had had to wait so long for this report. Part 2 consists of 171 closely printed pages of Russian text, all of it devoted to one part of the Kiik-Kobian man-the hand. Men of the early Pleistocene are represented by specimens from Java, China, Heidelberg and Piltdown; the later Pleistocene has given us a score or more of fossil Neanthalians, all from Mousterian sites, but of the men of the middle Pleistocene we know very little. It was the realization of this blank in our knowledge that made the author resolve to squeeze every item of information from the fossil bones of the Kiik-Kobian hand to an extent that has never before been attempted. $\mathrm{He}$ had at his disposal only two bones of the carpus (trapezium, trapezoid); two of the ten metacarpi (those of the thumb and ring finger); and fourteen phalanges of the fingers. Some of the bones belong to the right hand and some to the left; by using mirror-images of the left bones he was able to incorporate them into a reconstruction of the KiikKobian right hand. In the course of doing this he observed that those of the right were slightly the larger, pointing to right-handedness. To give his inferences a wide foundation, the author has extended his inquiries to the hands of modern man and of apes, and to the embryology of the hand of man and of apes; in short, he has constructed a new branch of inferential anatomy. He set out to give a description of a mid-Pleistocene European and ended by giving not only such a description but also what amounts to a treatise on the evolution of the human hand.

Kiik-Kobian man belongs to an age which precedes that which marks the appearance of Neanderthal man in Western Europe; he represents the folk of the upper or later Acheulean period of stone-culture. The only other site which had yielded fossil remains of Acheulean man, so far as M. Bonč-Osmolovskij could learn, was the Tabūn cave of Mount Carmel excavated (1929-34) by an expedition sent out by the British School of Archæology in Jerusalem and the American School of Prehistoric Research under the direction of Prof. Dorothy Garrod4. At Tabün the superimposed cave deposits reached the enormous depth of $80 \mathrm{ft} . ;$ as at Kiik-Koba, the bottom stratum was of the remote palæolithic age known as Tayacian; in this ancient stratum Kiik-Kobian man had been buried-the oldest human grave known to us as yet. Over the bottom stratum, at Tabün as at Kiik-Koba, come deposits of the later Acheulean,

- Paleolit Kryma. By G. A. Bonč-Osmolovskij. Vypusk 2 : Kist' iskopaemogo celoveka iz grota Kiik-Koba. (With a résumé in French.) Pp. $172+8$ plates. (M
1941.) 16.50 roubles. having a thickness of $16 \mathrm{ft}$. at Tabun. Then, at Tabun but not at Kiik-Koba, there follow strata$40 \mathrm{ft}$. of them-laid down during the period of Mousterian culture. The company of fossil Carmelites described by Dr. McCown and myself came from the deeper Mousterian layers. The Acheulean deposits yielded us only two fossil fragments-the greater part of the shaft of a femur and a worn lower molar tooth. We estimated the original length of the Tabūn femur, and from that gave the Tabūn Acheulean man a stature of $1.656 \mathrm{~m}$. (5ft. 5in.); the KiikKobian man is estimated (from the length of his tibia) to have been about $1 \cdot 59 \mathrm{~m}$. (5ft. $2 \cdot 6 \mathrm{in}$.). On comparing the femur and molar from the Acheulean deposits with the corresponding parts of the Mousterian Carmelites, we found a degree of correspondenee that led us to regard the Acheuleans of Tabūn as probably ancestral to the Carmelites. The cultural evidence, however, is against our supposition, for Prof. Garrod noted a definite change in the type of stone implement on passing from the Acheulean to the Mousterian strata.

There was no femur, no molar tooth, found at Kiik-Koba with which we might compare our Tabūn specimens. When, however, we compare the Crimean hand-bones with those of the Mousterian Carmelites, we find them sharing in certain features which are also present in the hand-bones of Neanderthal man, but not in those of modern man. But in their massiveness and in their ruggedness the hand-bones of KiikKobian man show a primitive characterization. $\mathrm{He}$ may well have been, as Bonc-Osmolovskij claims, ancestral to the Neanderthalians of Europe. Heidelberg man, who is known only by his lower jaw, has also a claim to be on the Neanderthalian ancestral line; a worn lower incisor, the only tooth found at Kiik-Koba, would be in place in a Heidelbergian mandible.

His painstaking methods have permitted M. BoncOsmolovskij to unfold a strange act of vandalism on the part of the Acheulean cave-men of Kiik-Koba. Not only had a man been buried in the bottom stratum, but also a child of about one year in age had been laid to rest near him, with its head directed towards his. Afterwards, for some unknown reason, the Acheuleans excavated and threw out that part of the floor of their cave which contained the graves, leaving in situ only the feet, right leg bones and parts of both hands of the man and those parts of the child which lie below the waist. Of the missing parts of the two individuals, only a worn lower incisor was recovered.

The author has my warm approval when he names this Crimean fossil type simply Kiik-Kobian manHomo kiik-kobiensis. Future discoveries will reveal his exact place in the scheme of human evolution. But I doubt if my British colleagues will agree with him in the place he assigns to his fossil type in the scale of time. He places it, not in the last great interglacial period-the Riss-Würm-but towards the end of the preceding interglacial, the Mindel-Riss. Miss D. M. A. Bate ${ }^{5}$ has reported on the fossil fauna from Tabun; she found that the chief change took place, not at the end of the Acheulean period, but towards the end of the Mousterian. Consequently the Acheulean as well as the Mousterian cultures at Tabūn are regarded as lying in the Riss-Würm interglacial.

Bonč-Osmolovskij gives the Kiik-Kobian the short, thick and squat hand of a labouring man; he was a labourer who used stone tools. He quotes Engels to 
the effect that "la main n'est pas seulement un organ de travail; elle en est aussi un produit". Our Carmelites also laboured with stone tools, but their hands had the shape and proportions still to be seen in native races. The author regards the squat, platelike hand and foot which appear in the embryonic stage of man and ape as the original primate type; Kiik-Kobian man, he believes, has retained this type. $\mathrm{He}$ seeks to explain the retention of the primitive form of hand in man by supposing that man never was a tree climber, as his anthropoid cousins became, but that he was evolved in treeless surroundings, such as those which now exist in South Africa. He follows with a lively interest the history of the fossil South African anthropoids as it is being unfolded by Dr. Robert Broom and Prof. Raymond Dart, and expects to find support for his theory from that source. I, on the other hand, regard the embryonic hand of man and ape as representative of a structure which never had existence outside the womb; the embryonic hand depicts a stage in development, not in evolution. I seek to account for man's form of hand by supposing that even in the arboreal stage of his evolution, when he was a climbing animal, his lower extremities and feet were his chief means of support; his hands were never modified to form hooks, as in his hand-clinging anthropoid cousins ${ }^{8}$.

My Russian colleague and I seem fated to construe prehistoric facts in a contrary manner. To him the fossil men of Java, of Peking, of Kiik-Koba, of Neanderthal, represent an ascending series which culminates, without a break, in Homo sapiens. For me, these pleistocene types represent separate evolutionary products, each being at a different stage of evolution. Bagehot showed a remarkable prescience when he declared (1869) that ancient races of mankind were "parish races". A transitional Neanderthal-Modern type has been discovered in Palestine but never in Europe. In Java, the early Pithecanthropoid is now linked to a later Australoid form by a series of fossil intermediates. The English contemporary of the Kiik-Kobians-the man whose skull was discovered deep in the Acheulean gravels at Swanscombe in the Thames valley by Mr. Alvan Marston in $1935^{7}$, was not at all Kiik-Kobian in type. So far as his characters can be made out, they link him, not to the Neanderthalians, but to the earliest known fossil type in Britain-Piltdown man ${ }^{8}$. Our evidence as it now stands is very imperfect, but such as it is, it entitles us to assume that the British peninsula of Europe had, in earliest pleistocene times, its own type of humanity.

Although my interpretations clash with those of my Russian colleague at several points, that does not blind me to the fact that he has made a contribution to our knowledge of the highest importance; he has enriched our modes of anthropological inquiry, as well as our armoury of fact. Students of human evolution await the monographs which will complete his Kiik-Kobian studies with a lively interest.

\footnotetext{
'Keith, Sir A., “New Discoveries relating to the Antiquity of Man" (1931), 363.

Childe, V. Gordon, Man, 98 (1942).

2 McCown and Keith, "The Stone Age of Mount Carmel. The Fossil Human Remains from the Levalloiso-Mousterian", 2 (1939).

"Garrod, D. A. E., and Bate, D. M. A., "The Stone Age of Mount Carmel", 1 (1937)

- See under 4, p. 139.

- Keith, Sir A., Amer. J. Phy8, Anthrop., 26, 251 (1940).

'Marston, Alvan T., J. Roy. Anthrop. Inst., 67, 339 (1937).

- Keith, Sir A., J. Anat., 73, 155 and 234 (1939).
}

\section{OBITUARIES}

\section{Prof. L. R. Wilberforce}

LIONEL ROBERT WIILBERForCE, eldest son of Edward Wilberforce, Master of the Supreme Court, and great-grandson of William Wilberforce, the emancipator, was born at Munich on April 18, 1861. After receiving his early education at the London' International College, Isleworth, he became a foundation scholar of Trinity College, Cambridge. He graduated as thirteenth Wrangler and obtained a first class in the Natural Science Tripos.

In 1887 Wilberforce was appointed assistant demonstrator to Sir J. J. Thomson at Cambridge, becoming demonstrator in 1890 and University lecturer in physics in 1900 . In the same year he succeeded Sir Oliver Lodge as professor of physics in the University of Liverpool, where he was at once faced with the planning of a new laboratory. This work was so well done that, except for limitations of space, it has satisfied most of the needs of presentday workers. It was in this laboratory that Barkla discovered the characteristic $X$-ray radiations of the elements. Some years previous to this, Wilberforce had suggested the now well-known method of investigating the polarization of $X$-rays, which in the able hands of Barkla provided the first real evidence of the undulatory nature of X-rays.

Judged by modern standards, the number of scientific papers published by Wilberforce is not large. His interests covered almost the wholp range of classical physics. In his Cambridge days he wrote on surface tension, viscosity, the vibration of loaded spiral springs and miscellaneous electrical topics. A fascinating product of his work on springs is the comparatively little-known Wilberforce spring which admirably illustrates the periodic transfer of energy from translation to rotation. Wilberforce was a strong advocate of the kinematic design of instruments. His kinematic clamps and boss head, which he described in a lecture to the Physical Society in 1932, have given much satisfaction in many laboratories. In his later years, Wilberforce became interested in the subject of electrical units, and was in frequent correspondence with the late Sir Richard Glazebrook. Arising from this were two penetrating papers on magnetism in the Proceedings of the Physical Society of 1933 and 1934.

Wilberforce was an excellent teacher. $\mathrm{He}$ had a thorough understanding of all types of students. For the beginner he wrote, with Fitzpatrick, "A Laboratory Note Book of Elementary Practical Physics". That he had a clear perception of the difficulties involved in the teaching of physics is brought out in the interesting chapter he contributed to "A History of the Cavendish Laboratory". He took great pains to make physics attractive to his students. His lectures were almost lavishly illustrated with experiments, the demonstration of which gave him much delight. In describing physical phenomenaalways in his own way-he seemed to prefer words to. symbols. It is, however, as a popular lecturer that he will be most widely remembered. He devoted an extraordinary amount of time to the perfection of his lecture demonstrations. He was quite early in the field with an ingeniously constructed wave: model and ripple tank which he exhibited on many occasions.

Wilberforce excelled as an administrator. His courtesy, ready wit, genial personality and clarity 